Institute of $\mathbf{F}_{\text {ood and }} \mathbf{A}_{\text {gricultural }} \mathbf{S}_{\text {ciences }}$

\title{
Farmers' Opinions about Bird Conservation and Pest Management on Organic and Conventional North Florida Farms 1
}

\author{
Susan K. Jacobson, Kathryn E. Sieving, Greg Jones, John McElroy, Mark E. Hostetler, Sarah W.
} Miller $^{2}$

Over 10 million acres of land are farmed in Florida. Farmers produced crops worth $\$ 6$ billion in 1997 (USDA 1999). With increasing population and development in Florida, agricultural lands also are becoming valuable wildlife habitat. Farm management could help increase wildlife numbers and diversity, especially for birds. Not only might farms benefit birds, but also birds might aid farmers. Insect-eating birds could help lower insect pest populations on farms. Thus, bird-friendly farming practices are of interest to farmers, biologists, consumers, and politicians.

Farms can provide good habitat for birds. However, some practices used by conventional farmers do not help sustain birds. These include increased use of pesticides and herbicides, and a shift toward specializing in one or a few crops. In contrast, organic agriculture in Florida includes certification that farmland has been free of synthetic pesticides for 3 years. Organic farms rely on biological interactions for pest control (called Integrated Pest Management, or IPM). Organic farmers usually grow many different crops. The Florida Certified Organic
Growers and Consumers Association must approve a management plan for each organic farm.

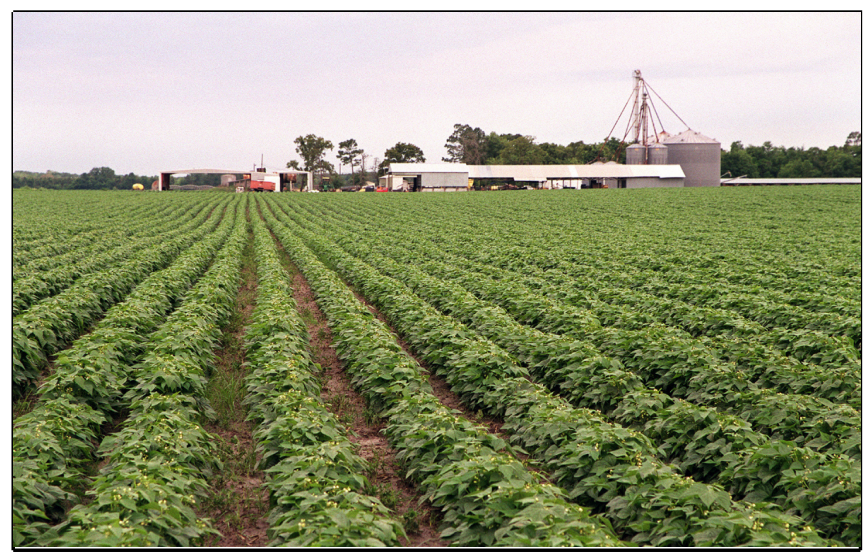

Figure 1. Farms can provide good habitat for birds as long as certain practices are adopted. Photo by Eric Zamora.

Despite these differences, both farm types could be managed to enhance bird habitat (Figure 1). Certain farm practices could help promote bird diversity. One strategy is to reduce pesticide use. Another is to increase plant diversity on a farm (Figure 2). Also, farmers could include perch sites in fields for foraging birds. All of these practices could

1. This document is Circular 1426, one of a series of the Wildlife Ecology and Conservation Department, Florida Cooperative Extension Service, Institute of Food and Agricultural Sciences, University of Florida. Original publication date: December 2002. Visit the EDIS Web Site at http://edis.ifas.ufl.edu for additional publications.

2. Susan K. Jacobson, Professor; Kathryn E. Sieving, Associate Professor; Greg Jones, Doctoral Candidate; John McElroy, Program for Studies in Tropical Conservation; Mark E. Hostetler, Assistant Professor; Sarah W. Miller, Wildlife Extension Program Assistant; Dept. of Wildlife Ecology and Conservation; Institute of Food and Agricultural Sciences, Cooperative Extension Service, University of Florida, Gainesville, FL 32611-0440, USA

The Institute of Food and Agricultural Sciences is an equal opportunity/affirmative action employer authorized to provide research, educational information and other services only to individuals and institutions that function without regard to race, color, sex, age, handicap, or national origin. For information on obtaining other extension publications, contact your county Cooperative Extension Service office. Florida Cooperative Extension Service/Institute of Food and Agricultural Sciences/University of Florida/Christine Taylor Waddill, Dean. 
increase numbers of insect-eating birds. However, farmers must be willing to take action. This requires an understanding of the knowledge and attitudes of farmers toward bird conservation.

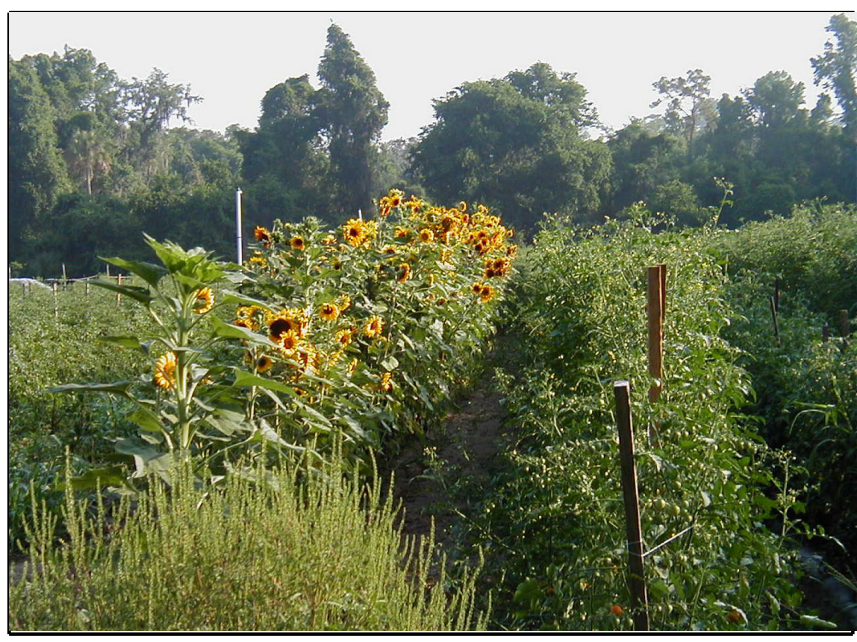

Figure 2. Organic farmers usually grow many different crops and rely on biological interactions and IPM strategies for pest control. Photo by Greg Jones.

We surveyed conventional and organic farmers about bird-friendly farming practices and pest management. We also wanted to better understand farmers' backgrounds. We included questions about social variables. Social variables included sex, age, education, income, and farm size. We asked about farmers' social networks. For example, which organizations have they joined? What are their extension and media contacts?

\section{Survey Methods}

We targeted farmers in northern Florida growing multiple vegetable and/or row crops. For our organic farmers sample, we obtained a list of certified organic growers in Florida from the Florida Certified Organic Growers and Consumers, Incorporated (Gainesville, FL). Thirty-nine organic farmers residing in 15 counties fit our criteria. All farmers were surveyed.

For conventional farmers, we obtained a list of 310 conventional farmers in 14 counties. This list was obtained from University of Florida Cooperative Extension agents in northern Florida counties. We randomly surveyed 105 farmers from this list.
Surveys were conducted by phone. Each survey lasted about 20 minutes. We completed a total of 76 survey interviews. Twenty-six organic farmers completed the survey. Fifty conventional farmers completed the survey.

\section{Survey Results}

\section{Social Structure}

Conventional farmers were primarily male (Table 1). They were older, had fewer years of formal education, and earned a higher income than organic farmers. The average age of conventional farmers was 53 years. The average age of organic farmers was 46. Past researchers have found that younger farmers with higher education levels are more likely to recognize harmful environmental effects. They were more willing to adopt new technologies that have less impact on the environment. Farmers with a higher income may show increased adoption of conservation techniques. This may be due to greater financial stability.

\section{Farm Characteristics}

Size. The average size of organic farms was 44 acres. This was smaller than conventional farms with an average of 786 acres. Almost one fifth of the conventional farms were more than 1000 acres. See Table 1 for more information.

Ownership. Considering all the survey participants together (conventional and organic), the majority of farmers owned their own farms.

Crops. Conventional farmers grew an average of 11 different crops. Organic farmers grew an average of 25 crops. Fifty percent of the conventional farmers grew 5 crops or less, and only $6 \%$ grew more than 15 crops. In contrast, $42 \%$ of the organic farmers grew more than 15 crops (Figure 2).

Income generated. Almost one half of all the farmers generated over $75 \%$ of their incomes from their farms.

Farm and family. About one third of the farmers had obtained their land from a family member. Only $25 \%$ of the farmers planned on their children farming their land. Forty-two percent did not plan on their 
children farming the land. About $27 \%$ were unsure (Table 1).

\section{Opinions About Pest Management}

Pest management was a greater concern to conventional farmers than to organic ones (Table 2). More conventional farmers reported that pest control is an important issue. More thought that insect pests cause considerable damage to their crops. They reported that leaf-eating insects are a serious problem. They stated that pest control costs a considerable amount of money.

Both conventional and organic farmers reported trying new pest management practices. Each looked for pests regularly, usually every day (Figure 3). However, more organic farmers looked for pests daily than conventional farmers. Organic farmers typically used Integrated Pest Management (IPM) principles. IPM is a strategy that uses multiple management techniques. IPM supports regular scouting for pests to reduce pesticide use (Figure 3).

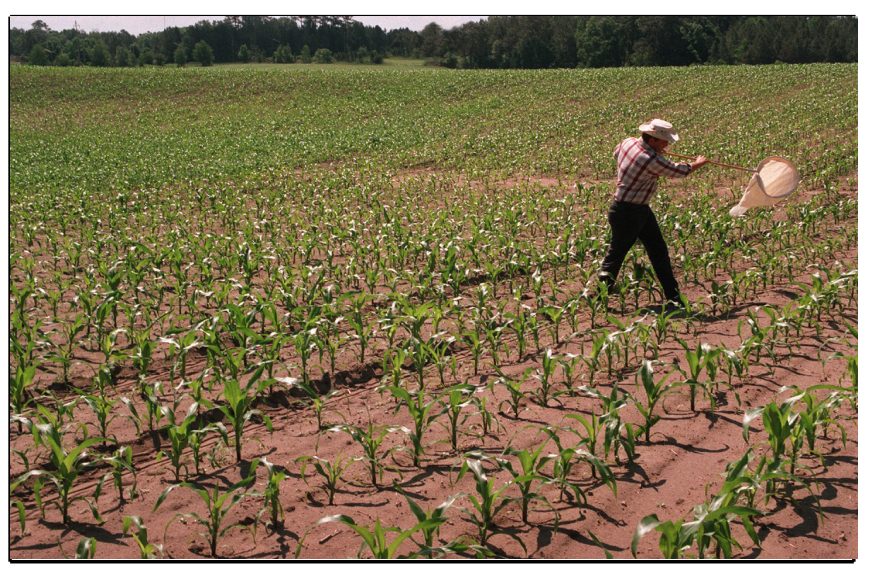

Figure 3. A farmer scouts for insect pests by sweeping a net through a portion of the crop. Regular scouting is one of multiple techniques in the Integrated Pest Management (IPM) approach to pest management. Farmers can reduce pesticide use by using techniques in IPM for pest control. Photo by Eric Zamora.

Further, the majority of all farmers thought their current pest management strategies did not affect the environment. Most were willing to use alternatives to pesticides. Most would spend more money for pest management that might benefit the environment.

\section{Opinions About Birds}

Conventional and organic farmers' opinions toward birds did not differ significantly (Table 2). Almost all farmers reported recognizing most of the bird species on their farms. About one half of the farmers reported seeing 10 to 20 different bird species on their farms. About $12 \%$ had observed more than 30 species of birds on their farms. More organic farmers than conventional farmers reported observing more than 30 bird species on their farms. These participating farmers' perceptions echo past research.

Past studies have shown more birds and an increased diversity of wild birds on organic farms. The reason for these differences is currently being studied by UF researchers. Organic farms may offer more suitable habitat and shelter for birds because of greater variety of vegetation; thus offering more food for birds.

Most farmers thought that birds could help lower insect populations on their farms. They would like to attract birds to their farms if they could lower insect pest populations (Figure 4). A third of the farmers reported already using methods to attract birds to their farms. These practices primarily included bird houses (Figure 4), feeders, and water sources.

Bird damage to crops was reported by $38 \%$ of all farmers. Crows were the primary culprits, damaging corn and watermelon crops. Conventional and organic farmers did not differ in reports of bird damage. They did not differ in actions to attract or repel birds. Only $12 \%$ of all farmers used methods to control bird damage to crops. These methods included noise cannons, use of netting around berry crops, and early picking of a crop.

\section{Incentives and Barriers for Bird-Friendly Farming}

In this study, most farmers were willing to attract birds to their farms. In past studies, farmer attitudes towards the environment have been negative in the U.S. In our survey, almost all of the farmers reported they do not object to having birds on their farm if they do not cause crop damage. These positive attitudes suggest opportunities exist to improve bird habitat on farms. 


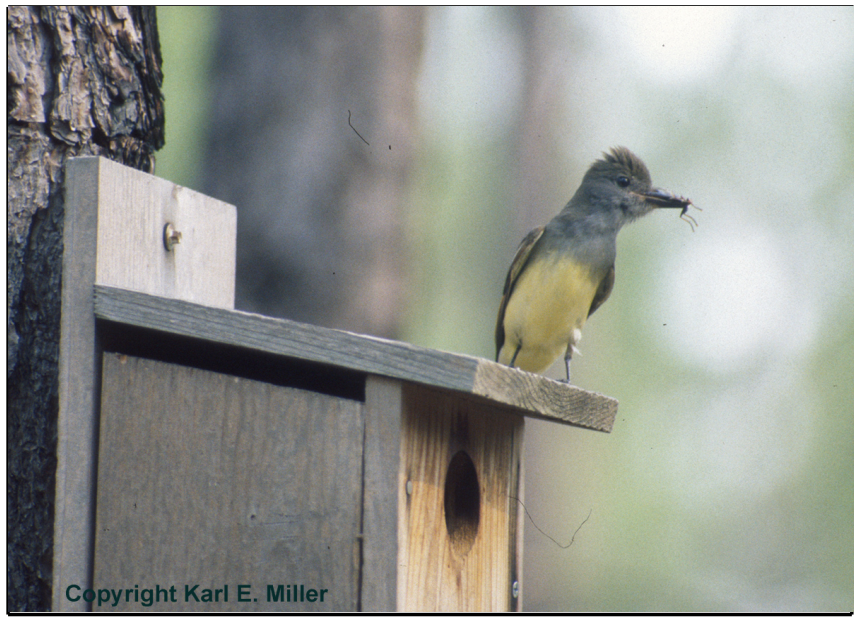

Figure 4. A Great-crested Flycatcher with insect in beak, perched on a nestbox. Insect-eating birds might aid farmers by helping to lower insect pest populations on farms. Photo used with permission from Karl E. Miller.

Certain factors could influence whether a farmer wants to attract birds. The following factors were explored to understand the barriers and incentives to establishing bird-friendly farms. One possible factor is that farmers would be more likely to want to attract birds for pest control if they had reported considerable pest control costs. Another was whether farmers who had experienced crop damage by birds would still want to attract birds to their farms. We also compared farmers who reported spending a lot to farmers who reported spending a little amount of money on pest control. Finally, we examined farmers' knowledge about insect-eating birds and birds on the farm. Our results showed that none of these factors influenced the participating farmers' willingness to attract birds to their farms.

More than $93 \%$ of all participating farmers thought that their farms already provide good habitat for birds -- regardless of farm type. Other studies suggest that there is a general tendency among farmers to over-rate the quality or efficiency of production or of a particular farming practice. Thus, farmers' high ratings of their farm habitat for birds suggest they may perceive only a limited need to change their practices. It makes little sense to expect a landowner to adopt new practices before recognizing a need. This must be addressed directly before introducing any new bird-friendly practices on farms.

\section{Social Participation and Communications}

Conventional and organic farmers obtain information in different ways. They also belong to different organizations (Table 3). Most of the conventional farmers in our study obtain their information from chemical companies. They also obtained information from UF/IFAS Cooperative Extension offices and Extension publications. Organic farmers obtain the majority of their information from the Florida Organic Growers Association. They also obtained information from various organic agricultural publications and Internet Web sites. If we are to make any changes in current farming practices to benefit birds, information must be made available to farmers through these channels.

Currently, specific information on how to enhance farms for birds is limited. However, we suggest that some simple practices could enhance bird habitat on farms. First, farmers can provide foraging perches, such as tall plants, watering devices, or other tall objects in fields. Second, farmers can manage for more natural vegetation on the farm. Examples include more trees, shrubs, and natural meadows. Such vegetation provides cover and food for birds. These two steps may increase populations of insect-eating birds on both conventional and organic farms.

In addition, more research is needed on how other physical, chemical, and biological elements of crop management affect bird populations. New farming methods are needed that sustain rather than reduce bird diversity. However, these practices must be relevant to ecological, economic, and social realities of farming.

\section{Acknowledgments}

Funding for this work was provided in part by the IFAS Florida First Initiative. We are grateful for the collaboration of more than 80 Florida farmers who provided their time and expertise to make this study possible. We thank J. Wu, S. Cook and A. van Doorn for assistance. We thank L. Branch for reviewing this manuscript. We thank M. Swisher and R. Koenig for expert advice and insightful review of the survey. An in-depth analysis of this study will be published in the journal Conservation Biology in 2003. 


\section{References}

Alston, D.G., and M.E. Reding. 1998. Factors influencing adoption and educational outreach of integrated pest management. Journal of Extension 36(3). (http://www.joe.org).

Cary, J.W. and R.L. Wilkinson. 1997. Perceived profitability and farmers' conservation behavior. Journal of Agricultural Economics 48:13-21.

Christensen, K.D., E.M. Jacobsen, and H. Nohr. 1996. A comparative study of bird faunas in conventionally and organically farmed areas. Dansk Ornithologisk Forenings Tidsskrift 90:21-28.

Fliegel, F.C. 1993. Diffusion research in rural sociology: The record and prospects for the future. Greenwood Press. Westport, Connecticut.

Fluetsch, K.M. and D.W. Sparling. 1994. Avian nesting success and diversity in conventionally and organically managed apple orchards. Environmental Toxicology and Chemistry 13:1651-1659.

Swisher, M.E., P. Monaghan, D. Schuster, and G.A. Brinen. April 1994. A profile of Florida's commercial organic vegetable farmers. Energy Extension Service-107. Florida Energy Extension Service, Florida Cooperative Extension Service, Institute of Food and Agricultural Sciences, University of Florida, Gainesville.

USDA (United States Department of Agriculture). 1999. 1997 Census of agriculture: Florida state and county data. U.S. Government Printing Office, Washington, DC 


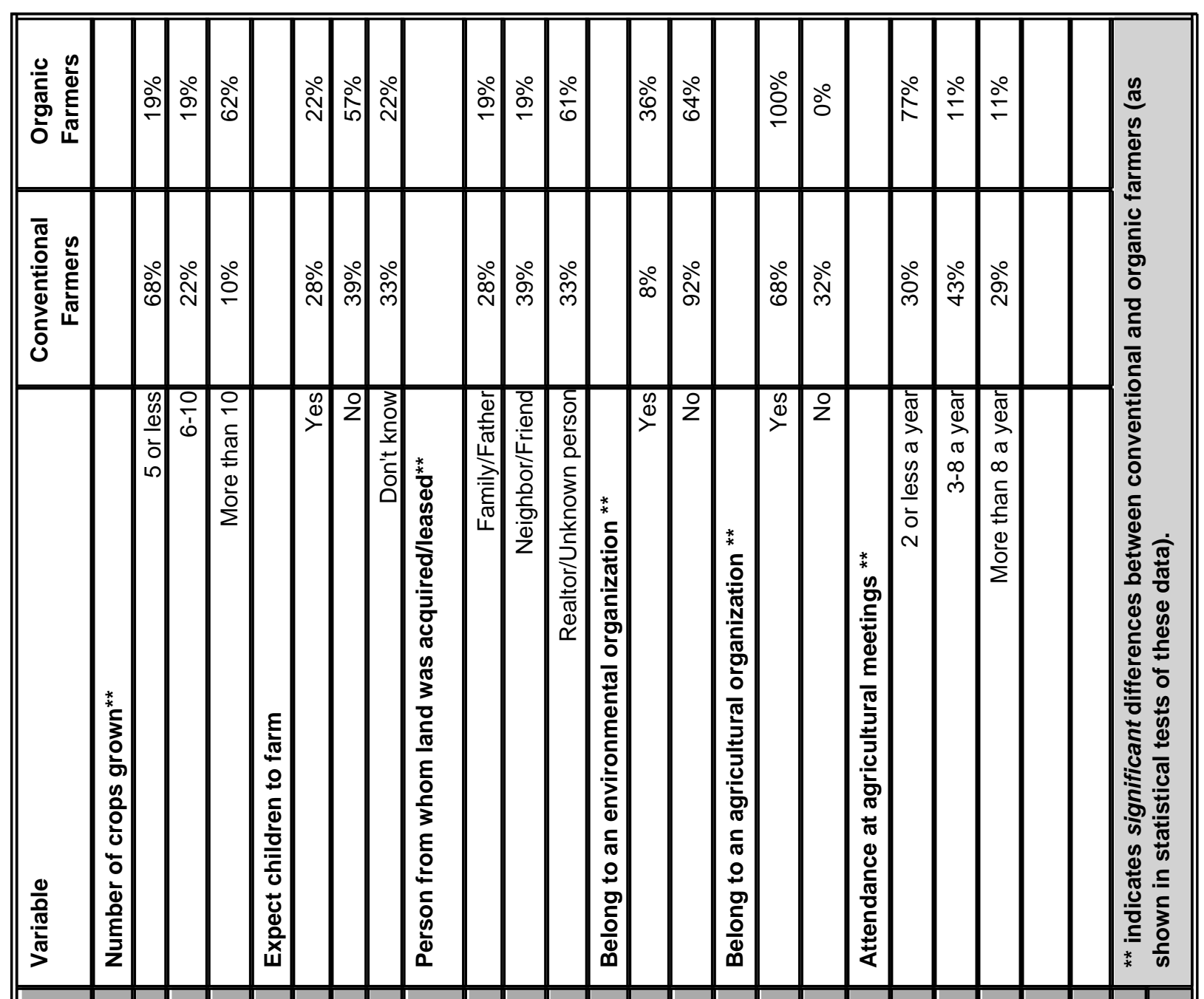

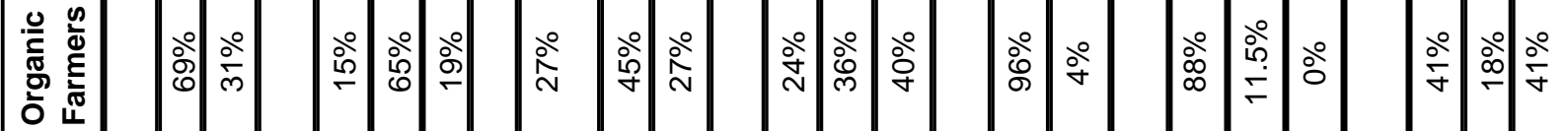
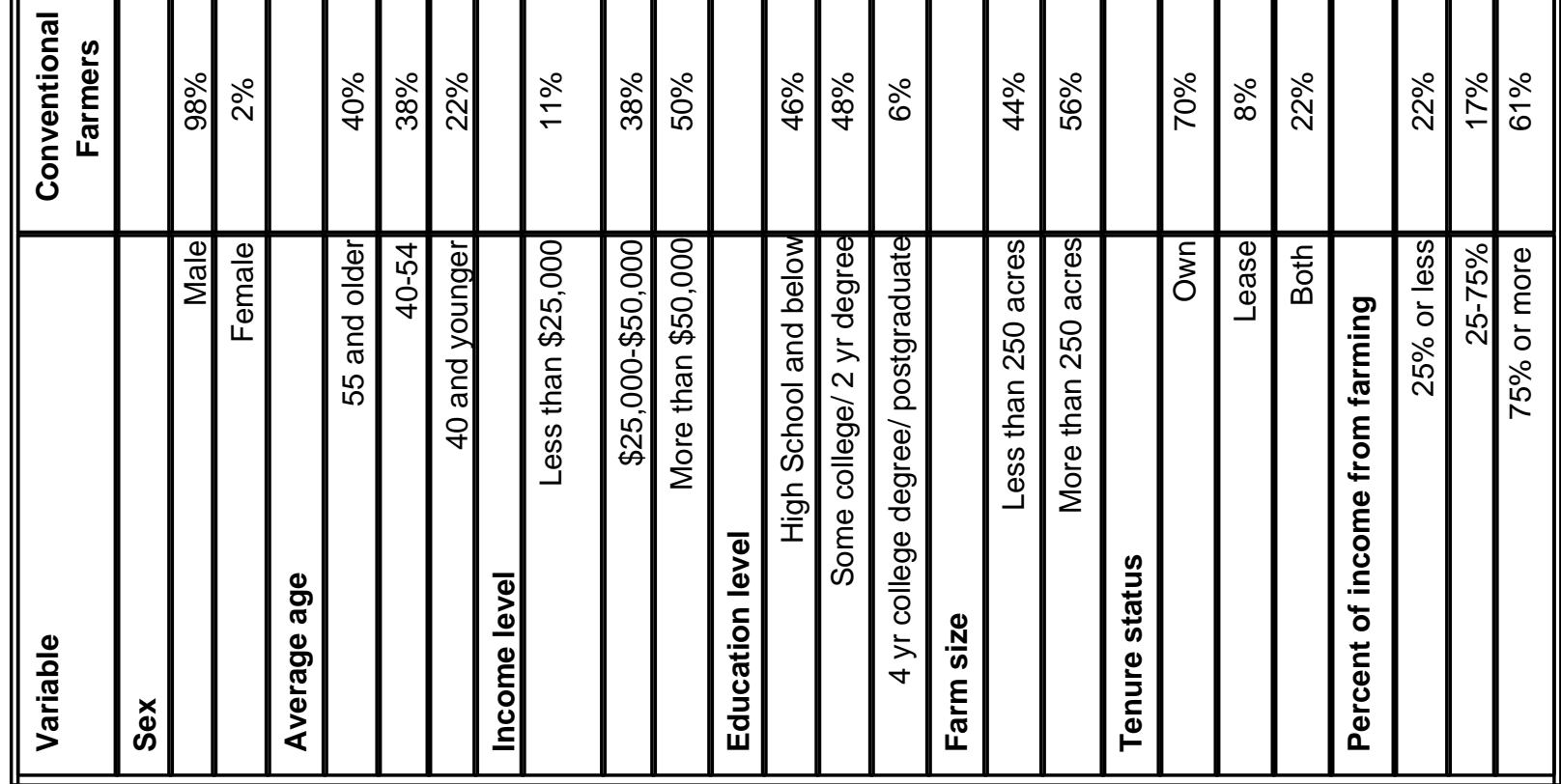
Table 2. Opinions of conventional and organic farmers about pest control and birds. (Survey based on responses from 50 conventional farmers and 26 organic farmers.)

\begin{tabular}{|c|c|c|c|c|c|c|}
\hline \multirow[b]{2}{*}{ OPINIONS } & \multicolumn{3}{|c|}{ CONVENTIONAL FARMERS (\%) } & \multicolumn{3}{|c|}{ ORGANIC FARMERS (\%) } \\
\hline & Agree & Neutral & Disagree & Agree & Neutral & Disagree \\
\hline Pest control is an important issue for me.** & $100 \%$ & $0 \%$ & $0 \%$ & $73 \%$ & $8 \%$ & $19 \%$ \\
\hline $\begin{array}{l}\text { Insect pests cause considerable damage } \\
\text { to my crops.** }\end{array}$ & $94 \%$ & $0 \%$ & $6 \%$ & $46 \%$ & $23 \%$ & $31 \%$ \\
\hline $\begin{array}{l}\text { I spend a considerable amount of money } \\
\text { on pest control. }{ }^{\star \star}\end{array}$ & $76 \%$ & $16 \%$ & $8 \%$ & $27 \%$ & $4 \%$ & $69 \%$ \\
\hline $\begin{array}{l}\text { I am satisfied with my current pest } \\
\text { management strategies. }\end{array}$ & $74 \%$ & $14 \%$ & $12 \%$ & $62 \%$ & $15 \%$ & $23 \%$ \\
\hline $\begin{array}{l}\text { I consider leaf-eating insects a serious pest } \\
\text { problem.** }\end{array}$ & $80 \%$ & $6 \%$ & $14 \%$ & $38 \%$ & $12 \%$ & $59 \%$ \\
\hline I look for pests regularly. & $94 \%$ & $2 \%$ & $4 \%$ & $96 \%$ & $0 \%$ & $4 \%$ \\
\hline $\begin{array}{l}\text { I sometimes try new pest management } \\
\text { strategies. }\end{array}$ & $64 \%$ & $12 \%$ & $24 \%$ & $81 \%$ & $0 \%$ & $19 \%$ \\
\hline $\begin{array}{l}\text { I think my current pest management } \\
\text { strategies do not affect the environment. }\end{array}$ & $88 \%$ & $8 \%$ & $4 \%$ & $89 \%$ & $0 \%$ & $12 \%$ \\
\hline $\begin{array}{l}\text { If there were effective alternatives to using } \\
\text { pesticides I would use them. }\end{array}$ & $90 \%$ & $6 \%$ & $4 \%$ & $92 \%$ & $4 \%$ & $4 \%$ \\
\hline $\begin{array}{l}\text { I would spend more money on pest } \\
\text { management that might benefit the } \\
\text { environment. }\end{array}$ & $76 \%$ & $18 \%$ & $6 \%$ & $88 \%$ & $4 \%$ & $8 \%$ \\
\hline $\begin{array}{l}\text { I recognize most of the different kinds of } \\
\text { birds on my farm. }\end{array}$ & $94 \%$ & $2 \%$ & $4 \%$ & $96 \%$ & $0 \%$ & $4 \%$ \\
\hline Birds cause damage to my crops. & $38 \%$ & $18 \%$ & $44 \%$ & $23 \%$ & $12 \%$ & $65 \%$ \\
\hline $\begin{array}{l}\text { Some birds do not cause damage to my } \\
\text { crops. }\end{array}$ & $98 \%$ & $0 \%$ & $2 \%$ & $96 \%$ & $0 \%$ & $4 \%$ \\
\hline $\begin{array}{l}\text { I do not mind having birds on my farm that } \\
\text { do not cause damage to crops. }\end{array}$ & $96 \%$ & $4 \%$ & $0 \%$ & $100 \%$ & $0 \%$ & $0 \%$ \\
\hline Some birds eat only insects. & $90 \%$ & $8 \%$ & $2 \%$ & $81 \%$ & $19 \%$ & $0 \%$ \\
\hline $\begin{array}{l}\text { Birds could help lower insect populations } \\
\text { on my farm. }\end{array}$ & $90 \%$ & $6 \%$ & $4 \%$ & $92 \%$ & $8 \%$ & $0 \%$ \\
\hline $\begin{array}{l}\text { I would like to attract birds to my farm if } \\
\text { they lowered insect populations. }\end{array}$ & $84 \%$ & $10 \%$ & $6 \%$ & $100 \%$ & $0 \%$ & $0 \%$ \\
\hline $\begin{array}{l}\text { I think my farm provides good habitat for } \\
\text { birds. }\end{array}$ & $92 \%$ & $4 \%$ & $4 \%$ & $96 \%$ & $4 \%$ & $0 \%$ \\
\hline
\end{tabular}


Table 3. Communications and social participation of conventional and organic farmers.

\begin{tabular}{|c|c|c|}
\hline \multicolumn{3}{|c|}{$\begin{array}{l}\text { Results for Survey Questions about } \\
\text { Communication and Social Participation }\end{array}$} \\
\hline $\begin{array}{l}\text { Primary Sources of Pest } \\
\text { Management Information }\end{array}$ & $\begin{array}{l}\text { Conventional } \\
\text { Farmers }\end{array}$ & $\begin{array}{l}\text { Organic } \\
\text { Farmers }\end{array}$ \\
\hline $\begin{array}{r}\text { University of Florida } \\
\text { Cooperative Extension } \\
\text { Service Agents }\end{array}$ & $68 \%$ & $4 \%$ \\
\hline Internet & $0 \%$ & $15 \%$ \\
\hline Publications & $28 \%$ & $46 \%$ \\
\hline $\begin{array}{r}\text { Chemical Dealers or } \\
\text { Labels }\end{array}$ & $20 \%$ & $0 \%$ \\
\hline Other Farmers & $2 \%$ & $31 \%$ \\
\hline $\begin{array}{l}\text { Farmers' Membership in } \\
\text { Agricultural Organization }\end{array}$ & $\begin{array}{l}\text { Conventional } \\
\text { Farmers }\end{array}$ & $\begin{array}{l}\text { Organic } \\
\text { Farmers }\end{array}$ \\
\hline Florida Farm Bureau & $48 \%$ & $19 \%$ \\
\hline $\begin{array}{r}\text { Florida Organic Growers } \\
\text { Association }\end{array}$ & $0 \%$ & $88 \%$ \\
\hline Cattleman's Associations & $16 \%$ & $0 \%$ \\
\hline Peanut Producers Associations & $16 \%$ & $0 \%$ \\
\hline $\begin{array}{l}\text { Farmer's Membership in } \\
\text { Environmental Organization }\end{array}$ & $\begin{array}{l}\text { Conventional } \\
\text { Farmers }\end{array}$ & $\begin{array}{l}\text { Organic } \\
\text { Farmers }\end{array}$ \\
\hline $\begin{array}{r}\text { Belong to one or more } \\
\text { environmental organizations }\end{array}$ & $8 \%$ & $35 \%$ \\
\hline \multicolumn{3}{|c|}{${ }^{\star \star}$ Surveyed farmers were allowed to list more than one source. } \\
\hline
\end{tabular}

